\title{
破裂性腹部大動脈瘤手術における左開胸併用法の検討
}

$$
\begin{aligned}
& \text { 櫻 井一村 瀬 允 也* 前田 正 信** } \\
& \text { 玉木修治西沢孝夫村山弘臣 }
\end{aligned}
$$

\begin{abstract}
当院で最近約 7 年半に腹部大動脈溜に対し 48 例に外科治療を行い, うち 13 例 (27.1\%) が破裂例であ った。ささらにこのなかで 6 例に対し左開胸を併用したが，この利点と欠点につき検討した．乥の結 果, 左開胸併用法では短時間で胸部大動脈遮断が可能で早期に脳や冠血流の循環動態を改善しえるこ と, 開腹から腹部大動脈遮断までの間の急激な大量出血にも迅速に対応できること, 開腹既往例の癒 着も関係ないことが利点と考えられた。一方問題点として, 遮断時間が限られること, 胸膜癒着例で は遮断までに時間を要すること, 呼吸不全合併例が増加する可能性があること, 出血量が増加する可 能性があること, 胸部大動脈石灰化や瘤合併例では解離性大動脈瘤, 瘤破裂などを新たに起こしうる ことなどがあげられた，今後は, 本法の長短所を理解し, 左開胸併用法とともにバルーンカテーテル 法も症例により選択していく必要があると考えられた。目外会誌 26 巻 1 号：16-21（1997）
\end{abstract}

Keywords：破裂性腹部大動脈瘤, 左開胸

\section{Left Thoracotomy in the Treatment of Ruptured Abdominal Aortic Aneurysms}

Hajime Sakurai, Mitsuya Murase*, Masanobu Maeda**, Syuji Tamaki, Takao Nishizawa and Hiromi Murayama (Department of Thoracic Surgery, Ohgaki Municipal Hospital, Ohgaki, Japan, Department of Thoracic Surgery, Nagoya University*, Nagoya, Japan and Department of Cardiovascular Surgery, Shakaihoken Chukyo Hospital**, Nagoya, Japan)

Thirteen cases of ruptured abdominal aortic aneurysm were treated during a period of 7 years and 5 months. In 6 cases, left thoracotomy was used before laparotomy to clamp the descending thoracic aorta. The merits and demerits of this method were evaluated in this study. It is useful for early improvement of cerebral and coronary circulation and prevention of sudden spurting hemorrhage, especially in cases with the previous laparotomies. On the other hand, this method has a shorter clamp time limit and requires much time in cases with pleural adhesions. It may increase the amount of operative bleeding and the incidence of postoperative respiratory insufficiency. It may also cause an intraoperative thoracic aortic dissection and rupture of thoracic aortic aneurysms if present. It is considered that this method is advantageous, but should be used only in selected cases. Jpn. J. Cardiovasc. Surg. 26 : 16-21 (1997)

破裂性腹部大動脈瘤の手術成績はいまだに満足 できるものではなく，死亡率も $40 \%$ 前後という 報告が多くみられる1 5)。また，手術成績に大き な影響を及ぼす因子の一つに術前のショック状態 の有無がいわれており，いち早くショック状態よ り離脱させることが救命率の向上につながるもの と考えられる。この見地からわれわれの施設で は, 術前にショック状態を呈しているような症例 に対しては, 左開胸を行い下行胸部大動脈をいつ でも遮断できるように準備して，あるいは遮断し

1996 年 1 月 12 日受付，1996 年 5 月 10 日採用

大坦市民病院胸部外科 $=503$ 大垣市南规町 4-86

*名古屋大学胸部外科

**社会保険中京病院心臟血管外科
た状態で開腹している。今回おもに左開胸を併用 した破裂性腹部大動脈瘤手術症例について検討し たので，その有効性と問題点につき報告する.

\section{対象と方法}

当院で 1987 年 11 月から 1995 年 3 月までの 7 年 5 か月間に，腹部大動脈瘤に対し外科治療を行 ったものは48例あり,これらを対象とした(図 1 )。このうち 35 例 $(72.9 \%)$ が非破裂性の待機的 手術例 ( R ( - ) 群)で, 13 例 $(27.1 \%)$ が破裂性の緊 急手術症例 $(\mathrm{R}(+)$ 群)であった。さらに破裂例の なかで，左開胸を併用しなかったものが 7 例あり $(\mathrm{R}(+) \& \mathrm{~T}(-)$ 群), 開腹に伴って大量出血が危 


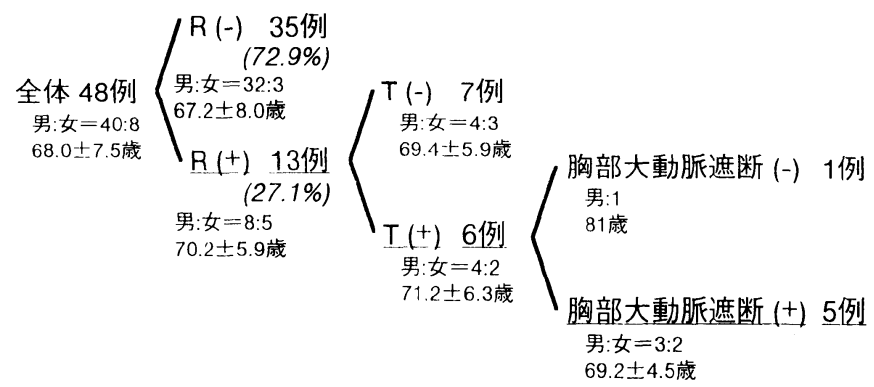

図 1 腹部大動脈瘤手術症例 $(1987.11$ ～1995.3.)

表 1 術式と手術成績

\begin{tabular}{crcc}
\hline & & \multicolumn{3}{c}{ 入院死亡例 $(\%)$} \\
\hline 全体 48 例 & & 3 例 & $(6.3)$ \\
$\mathrm{R}(-)$ & 35 例 & 0 例 & $(0.0)$ \\
$\mathrm{R}(+)$ & 13 例 & 3 例 & $(23.1)$ \\
$\mathrm{T}(-)$ & 7 例 & 1 例 & $(14.3)$ \\
$\mathrm{T}(+)$ & 6 例 & 2 例 & $(33.3)$ \\
\hline
\end{tabular}

惧されたり，輸液でも血圧が維持できずショック 状態を脱しえなかった 6 例に対しては左開胸を併 用した $(\mathrm{R}(+) \& \mathrm{~T}(+)$ 群)。実際に下行胸部大動 脈を遮断したものはうち 5 例であった。各群の年 齢および性別は図 1 のごとくであった。

手術は, 48 例中 41 例に Y 型人工血管移植術 を，4 例に直型人工血管移植術を，2 例に腋窩動 脈両大腿動脈バイパス術を行い，残り１例は破裂 例で心肺蘇生を行いながら手術室に搬送したもの の蘇生に反応せず開腹術のみで終わった。開胸例 では患者を右半側臥位とし，開腹と同時，あるい はやや先行して左第 6 または 7 肋間前方開胸を行 い, 下行胸部大動脈周囲を遮断鉗子が入る分のみ 最低限剥離し，症例に応じて開腹前，または開腹 後腹部大動脈の剝離前に遮断した。各群の術式の 内訳は表 1 に示した。

それぞれの手術成績, 輸血量, 合併症と頻度を 比較し，とくに $\mathrm{R}(+) \& \mathrm{~T}(+)$ 群については麻 酔導入から大動脈遮断までの時間と血圧の変化も 検討した。

\section{結果}

\section{1. 手術成績(表 1)}

全症例の 48 例では， 3 例 $(6.8 \%)$ の入院死亡が

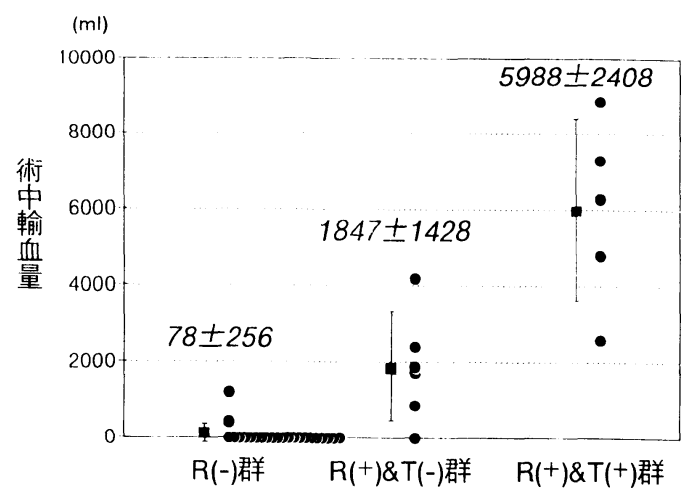

図 2 輸血量の比較

あり， $\mathrm{R}(-)$ 群の死亡例はなく， $\mathrm{R}(+)$ 群では 13 例中 3 例 $(23.1 \%)$ の入院死亡であった。 $\mathrm{R}(+) \&$ $\mathrm{T}($ (一)群の 7 例のうち 1 例を出血で失ったが，こ れは先に述べた開腹のみで終わった症例である。 また， $\mathrm{R}(+) \& \mathrm{~T}(+)$ 群の 6 例のうち 2 例を失っ た. 1 例は呼吸停止状態で来院し, 麻酔導入時に 心停止となって胸部大動脈を遮断し蘇生しつつ手 術を行ったが出血で失い，他の 1 例は左開胸を行 ったが胸部大動脈の遮断は必要としなかったもの の術後急性腎不全から多臓器不全となり失ったも のである。

\section{2. 術中輸血量 (図 2 )}

全例に自己血回収装置を用いており出血量の正 確な計測が不可能であったため，間接的な指標で ある輸血量を, $\mathrm{R}(-)$ 群, $\mathrm{R}(+)$ \& $\mathrm{T}(-)$ 群, $\mathrm{R}$ $(+) \& T(+)$ 群の 3 群で比較した. 当然 $\mathrm{R}(-)$ 群で最も輸血量が少なく 35 例中 4 例 $(11.4 \%)$ に 輸血を要したのみで, 輸血量は平均 $78 \pm 256 \mathrm{ml}$ であった。 $\mathrm{R}(+)$ 群では 13 例中 12 例 $(92.3 \%)$ に 輸血を要した。とくに， $\mathrm{R}(+) \& \mathrm{~T}(+)$ 群で輸血 
表 2 術後合併症の比較

\begin{tabular}{|c|c|c|c|}
\hline & $\mathrm{R}(-)$ 群 & $\mathrm{R}(+) \& \mathrm{~T}(-)$ 群 & $\mathrm{R}(+) \& \mathrm{~T}(+)$ 群 \\
\hline 呼吸不全 & $1 / 35 \quad(2.9 \%)$ & & $2 / 5 \quad(40.0 \%)$ \\
\hline 腎障害 & & $1 / 6 \quad(16.7 \%)$ & $2 / 5(40.0 \%)$ \\
\hline 肝·障恝 & & $1 / 6(16.7 \%)$ & \\
\hline 胆囊炎 & & & $1 / 5(20.0 \%)$ \\
\hline 胃潰瘍 ～～～～ & $1 / 35 \quad(2.9 \%)$ & & \\
\hline グラフト感染 & $1 / 35 \quad(2.9 \%)$ & & \\
\hline 創感染 & $3 / 35(8.6 \%)$ & $1 / 6 \quad(16.7 \%)$ & \\
\hline 後腹膜血腫 & $1 / 35 \quad(2.9 \%)$ & & \\
\hline
\end{tabular}

(術中死亡の 2 例を除く)

量が最も多く，平均 $5988 \pm 2408 \mathrm{ml}$ であった。

\section{3. 術後合併症 (表 2 )}

術中死亡の 2 例を除き，同じく 3 群間で術後合 併症の種類と頻度を比較した。とくに術後 3 日以 上の人工呼吸器管理を必要とした呼吸不全の頻度 が， $\mathrm{R}(+) \& \mathrm{~T}(+)$ 群で 5 例中 2 例 $(40.0 \%)$ と高 率であった。この 2 例はまた気管切開を要した。 他に術後クレアチニン值が $2.5 \mathrm{mg} / \mathrm{dl}$ 以上に上 昇した腎機能障害例が，やはり $\mathrm{R}(+) \& \mathrm{~T}(+)$ 群で高率であった。しかし，術前のショック状態 の程度からみると $\mathrm{R}(+) \& \mathrm{~T}(+)$ 群ではより高 度な症例が多く含まれ，また腎動脈より中枢側で ある胸部大動脈での遮断がこれを助長したことが 考えられた。

\section{4. 胸部大動脈遮断までの時間と体血圧の変化} (図 3)

$\mathrm{R}(+) \& \mathrm{~T}(+)$ 群 6 例のうち穾際に胸部大動脈 遮断を行った 5 例で, 麻酔導入から胸部大動脈遮 断までの時間をみると, 胸膜の癒着がなかった 3 例では約 10 分で遮断が可能であった（図 3 a). しかし， 2 例で胸膜に聡着があり 65 分, 90 分と 予想以上の時間を要した。1例は癒着を剥離しな がら胸部大動脈に達し，もう１例は癒着が高度で あったため胸膜外で胸部大動脈に達した。幸いに もこの 2 例は麻酔導入時にはショック状態は軽度 で切迫した状況ではなく腹部手術の既往があった ため，なかば予防的に左開胸を併用した症例であ ったため手術にはとくに問題なく経過し救命しえ た。また，体血压の変化についてみると胸部大動 脈の遮断によりいずれも上半身の血圧を 80 a

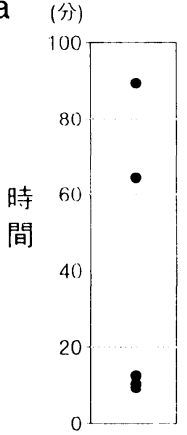

図 3 麻酔導入から胸部大動脈遮断までの時間と血圧 変化

麻酔導入から胸部大動脈遮断までの時間 ( a ), 麻酔導入から胸部大動脈遮断までの血圧変化 (b).

$\mathrm{mmHg}$ 以上に維持することが可能となった（図 3 b). 胸部大動脈から腹部大動脈に遮断しなおす までの時間は平均 $18 \pm 5.5$ 分 (14〜25 分)であっ た.

\section{考察}

破裂性腹部大動脈瘤に対する手術成績は，諸家 の報告でも死亡率は 29～58\%と高率である ${ }^{1 \sim 5)}$. また，手術成績に影響を及ぼす因子として，来院 時の収縮期血圧，ショック状態の持続期間，代謝 性アシドーシスの存在，周術期の心停止などが指 摘されて㧈り ${ }^{3,5)}$. いち早くショック状態から離 脱させることが救命率の向上につながるものと考 えられる。この見地からわれわれの施設では，1） 輸液のみで術前ショック状態を脱しえず安定した 
血行動態を維持できないような症例，2)術前腹部 CT などの画像診断で高位の腹部大動脈の周囲を 中心として血腫が存在し腹部大動脈の剥離時に再 出血が危惧される症例，3) 上腹部の開腹術の既往 があり腹部大動脈の剝離に時間を要すると思われ る症例に対しては, 開腹前か同時進行で左開胸を 行い下行胸部大動脈をいつでも遮断できる状態に して，あるいは遮断した状態で開腹している。 左開胸併用法の利点はすでに報告されてい る ${ }^{6)}$.すなわち, 第一にあらかじめ下行胸部大動 脈をいつでも遮断できるような状態にしておけぱ 開腹から腹部大動脈の遮断までの間の急激な大量 出血に対して迅速な対応が可能であることがあげ られる。とくに開腹術の既往のある症例で消化管 の癒着のため腹部大動脈の遮断が遅れ出血のため 術中心停止をきたした症例も報告されており4), 腹部大動脈瘤のより中枢側の大動脈周囲に癒着や 血腫が存在するような場合には有効と思われる。 第二の大きな利点として, 胸部大動脈の遮断まで の時間と体血圧の変化で示したように多くの症例 では手術開始から10 分程度で下行胸部大動脈の 遮断が可能であり, 術前重篤なショック状態を伴 つた症例でもより早期に上半身の血圧を 80 $\mathrm{mmHg}$ 以上に維持することが可能となり，最も 優先されるべき脳や冠血流が保たれることであ る。その他，開腹術の既往のためなかば予防的に 左開胸を併用する場合には，開胸と開腹の同時進 行も一つの選択枝と考えられる。

一方，いくつかの問題点も有している。一つに は，下行胸部大動脈遮断により，肝，腎および脊 髄など重要藏器への血流が遮断されるため, 遮断 時間に大きな制限があることである。自験例では 下行胸部大動脈から腹部大動脈に遮断しなおすおま でに要した時間は平均 18 分，最大 25 分であり， この時間内では幸いにも術後対麻痺や肝機能障害 の発生はみられなかった。また，1例で術後クレ アチニン值が最大 $4.5 \mathrm{mg} / \mathrm{dl}$ まで上昇したが透 析など特別な治療を必要とすることなく回復して おり，術前から体血圧が $60 \mathrm{mmHg}$ 前後のショッ ク状態を伴っており単に下行胸部大動脈の一時的 遮断が原因とは断定できない。しかし，ほぼ常温 での遮断となることから今後問題となることもあ
りうると思われる。

胸膜が癒着していた 2 例では，下行胸部大動脈 遮断までに 65 分と 90 分を要しており，これはい ずれも開腹術の既往がありなかば予防的に開胸を 行い, ショック状態も軽度で開腹を急ぐことなく 止血も丁寧に行うことができた.しかし，今後症 例により迅速に上半身の血圧を上昇させる必要が あることも十分考慮する必要がある。

自験例において術後 3 日以上の人工呼吸器を用 いた呼吸管理を要した呼吸不全の発生は $\mathrm{R}($ (一)群 で $2.9 \%, \mathrm{R}(+)$ \& $\mathrm{T}($ (一)群ではみられなかった にもかかわらず， $\mathrm{R}(+) \& \mathrm{~T}(+)$ 群では 5 例中 2 例にみられた。したがって, 開胸操作により呼吸 不全の合併率が増加した可能性が考えられた，森 山らは77, 腹部大動脈瘤待機手術症例 103 例中 32 例 (33.3\%) に術前呼吸機能障害 $(\% \mathrm{VC}<80 \%$, FEV 1.0\%<70\%) を合併していたと報告してお り，破裂例でも同様な高頻度で術前すでに呼吸機 能障害を合併していると考えられる。このような 症例では開胸操作によりとくに術後呼吸不全を合 併しやすいと思われ注意を要する。

術中輸血量は, $\mathrm{R}(+) \& \mathrm{~T}(+)$ 群で最も多いと いう結果がえられた。こ0群に重症例が多く含ま れると思われるため一概にはいえないが，大量輸 血を行い凝血能が低下しているような状況下で左 開胸操作を加えることによりさらに出血量が増加 した可能性が示唆された。

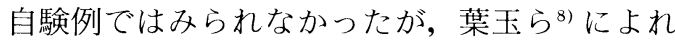
ば，非破裂性腹部大動脈瘤症例 56 例中 4 例 ( $7 \%$ ) に術前から胸部大動脈瘤を合併していたと 報告し，また術後 8 日目で胸部大動脈溜破裂をき たしたという報告 ${ }^{2}$ や，耐術例 96 例の追跡調查 において 15 例の遠隔死亡中 1 例が胸部大動脈瘤 破裂によるものだったという報告7もみられる。 これらの報告からみても, 術中胸部大動脈に高度 の石灰化や胸部大動脈瘤を合併している症例で は，胸部大動脈の遮断が困難であったり，遮断鉗 子により大動脈解離，瘤破裂などを新たに起こし うる危険性もあるものと考えられる。

以上のような問題点を克服する方法として，バ ルーンカテーテル挿入による大動脈遮断法 ${ }^{1 \sim 3,9,10)}$ が考えられる，文献上この方法の利点として，術 
湔门に局所麻酔下で挿入可能であり麻酔導入時の血 生低下にも対処できること ${ }^{1,2)}$, 開胸と同じく 15 分前後の短時間で挿入が可能なこと年，バルー ンの搪張部位は，腎動脈上部の腹部大動脈という 報告 ${ }^{2)}$ もられるが, 腎動脈下瘤破裂の場合には 動脈溜の近位側でバルーンを拡張させることによ $り^{1)}$ Adamkiewicz 動脈, 腹腔動脈, 上腸間膜動 脈，腎動脈の血流も保った状態で上半身の血圧を 上昇させ維持できること帛，カテーテル挿入例で

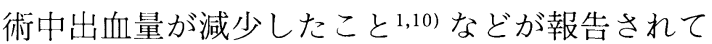
いる。この他, 胸膜癒着例や胸部大動脈の高度石 灰化例には開胸法より有利な方法であると考えら れる。

しかしながら, 開胸法と比較してバルーンカテ ーテル法にも種々の問題点が報告されている。す なわち, 遮断が不確実となる可能性 ${ }^{2,5}$, 鎖骨下 動脈屈曲や狭窄例で挿入困難な症例 ${ }^{1,3)}$ ，鎖骨下 動脈のカテーテルによる穿孔例3)，心停止下では 挿入がより困難であること"1，バルーンを適切な 位置に固定するのに時間を要する可能性, 拡張部 位が不適当であると肝, 腎, 脊髄などの血流が遮 断され，実際に肝不全や血圧上昇による脳出血の 報告1)などがみられる。

その他の方法として近位側腹部大動脈の用手的 圧迫法も報告されている ${ }^{11}$. しかし，腹部大動脈 に達する過程で制御不能な出血に陥ったり，視野 が不良で副損傷の可能性があること，不完全遮断 となることなどから, 開胸法やバルーンカテーテ ル法に比し危険が高いのではないかとも考えわれ われは用いていない。

過去約 7 年半にわたり, 破裂性腹部大動脈瘤症 例に対し左開胸併用法により上記の方針で望んで きたが，症例数は 13 例と多くはないものの入院 死亡率は $23.1 \%$ と比較的良好な結果が得られた。 今回の検討で本法は，ショック状態の合併例，開 腹術既往例, 腹部大動脈剝離中の大量出血の予防 などに有効である反面，前述したごとく種々の問 題点も明らかとなった。左開胸併用法とバルーン カテーテル法の優劣はつけがたく，要はどちらか の方法に習熟し，両者の長所，短所を理解し症例 によっていずれの方法も用いうる体制を整えてお くことが肝要ではないかと思われる，当施設では
胸部外科という性格上開胸には手慣れているた め, 今後も左開胸併用法を第一選択とし，場合に よりバルーンカテーテル法も用いていきたいと考 えている．

\section{結語}

左開胸を併用した破裂性腹部大動脈瘤手術症例 の有効性と問題点を検討した。

左開胸の利点として, 短時間で胸部大動脈の遮 断が可能で早期に上半身，とくに脳や冠血流の循 環動態を改善しうること, 開腹から腹部大動脈遮 断にいたるまでの急激な大量出血に迅速に対応で きること，開腹術既往例の腸管癒着もあまり影響 されないことである。一方, 問題点として, 遮断 時間が限定されること, 胸膜癒着例では遮断まで に時間を要すること, 呼吸不全合併例が増加する 可能性があること, 術中出血量が増加する可能性 があること，胸部大動脈の石灰化や瘤合併例では 大動脈解離，瘤破裂などを新たに起こしうること などがあげられる。

他にバルーンカテーテル法の有効性も報告され ているがまた種々の問題点もあるため, 今後は, それぞれの長所, 短所を理解し, 左開胸併用法と バルーンカテーテル法を症例に応じて選択してい く必要があると考えられる。

\section{文献}

1）諸星保憲, 大熊恒郎, 佐藤 成ほか：腹部大動脈, 腸骨動脈瘤破裂例の検討一Balloon occlusion catheter 使用例を中心に一. 日心外会誌 $21 ： 383-$ 387, 1992.

2）前田信証，宮本 巍，村田紘崇ほか：破裂性腹部 大動脈瘤の外科治療一手術成績向上のための工 夫一. 日心外会誌 $21 ： 388-391,1992$.

3）安達盛次, 安藤太三, 中谷 充ほか：腹部大動脈 瘤破裂例の手術一ショックに対する対応と成績 の向上一. 日心外会誌 21：396-399, 1992.

4）須藤憲一, 小石沢正, 津田京一郎ほか：腹部大動 脈瘤の外科治療一とくに開腹既往症例に対する 検討一. 日心外会誌 $23 ： 78-83,1994$.

5）森山由紀則, 豊平 均, 西元寺秀明ほか：破裂性 腹部大動脈瘤症例の検討一手術成績に関連の因 子と遠隔予後の検討一. 日心外会誌 $23 ： 186-190$, 1994.

6）末田泰二郎, 渡橋和政, 呑村孝之ほか：破裂性腹 部大動脈瘤の外科治療に抢ける左開胸併用法の 
有用性. 日心外会誌 $23: 88-91,1994$.

7）森山由紀則, 豊平 均, 橋口雅彦ほか：腹部大動 脈瘤待機手術 103 例の検討一術後合併症と遠隔 予後よりみた危険因子の検討一。日心外会誌 $23: 167-171,1994$.

8）葉王哲生, 調 亟治, 高橋英巳ほか：腹部大動脈 瘤の手術成績向上のための工夫とその長期予後. 日心外会誌 $21 ： 17-23,1992$.

9) Smith, F. G.: Emergency control of ruptured abdominal aortic aneurysm by transaxillary balloon catheter. Vasc. Surg. 6: 79-84, 1972.

10）佐々木久夫, 前山俊秀, 大熊恒雄ほか：破裂性腹 部大動脈溜，とくにバルーンカテーテルを用いた 緊急時大動脈遮断法について. 日心外会誌 15： 161-162, 1985.

11）内田發三, 杉山 悟, 中井幹三ほか：破裂性腹部 大動脈瘤の手術成績と手技上の工夫. 日心外会誌 21 : 392-395, 1992. 